\title{
Evaluation of Structural Integrity for High Rise Buildings Using Non-Destructive Test Method
}

\author{
M. S. Muhd Norhasri ${ }^{1,2, *}$, H. Mohd Shafee ${ }^{1}$, J. Nurliza ${ }^{1}$, M. F. Mohd Afiq ${ }^{1,2}$, A. Anizahyati ${ }^{1,2}$, \\ H. Rohana ${ }^{1,2}$, A. H. Norhayati ${ }^{1,2}$, A. S. Dzulkafley ${ }^{3}$ \\ ${ }^{1}$ Institute for Infrastructure Engineering and Sustainable Management (IIESM), Universiti Teknologi MARA (UiTM), Shah Alam, \\ Selangor, Malaysia \\ ${ }^{2}$ School of Civil Engineering, College of Engineering, Universiti Teknologi MARA (UiTM), Shah Alam, Selangor, Malaysia \\ ${ }^{3}$ AKS Consulting Sdn. Bhd, Kuala Lumpur, Malaysia
}

Received May 19, 2021; Revised June 30, 2021; Accepted July 25, 2021

\section{Cite This Paper in the following Citation Styles}

(a): [1] M. S. Muhd Norhasri, H. Mohd Shafee, J. Nurliza, M. F. Mohd Afiq, A. Anizahyati, H. Rohana, A. H. Norhayati, A. S. Dzulkafley, "Evaluation of Structural Integrity for High Rise Buildings Using Non-Destructive Test Method," Civil Engineering and Architecture, Vol. 9, No. 5, pp. 1421 - 1433, 2021. DOI: 10.13189/cea.2021.090515.

(b): M. S. Muhd Norhasri, H. Mohd Shafee, J. Nurliza, M. F. Mohd Afiq, A. Anizahyati, H. Rohana, A. H. Norhayati, A. S. Dzulkafley (2021). Evaluation of Structural Integrity for High Rise Buildings Using Non-Destructive Test Method. Civil Engineering and Architecture, 9(5), 1421 - 1433. DOI: 10.13189/cea.2021.090515.

Copyright $\bigcirc 2021$ by authors, all rights reserved. Authors agree that this article remains permanently open access under the terms of the Creative Commons Attribution License 4.0 International License

\begin{abstract}
Concrete structure is one of the common construction materials in the world. The reliability in terms of performance, durability and cost effective are the major advantages in utilising concrete as construction material. However, due to time and workmanship, concrete is prone to deterioration. In this study, three main beam size of 400 $\mathrm{mm} \times 1200 \mathrm{~mm}$ in size is evaluated in terms of structure integrity using Non-Destructive Test. Ultrasonic Pulse Velocity (UPV) is adapted to determine the concrete quality. For durability aspects, the utilisation of X Ray Fluorescence (XRF) with rapid carbonation kit is adapted. From this finding, one of the beams inspected is detected with poor quality. This is supported by visual for crack detection and voids in all beam. Elementary for concrete quality for all beams is confirmed using XRF and supported with carbonation kit. In conclusion, the outcome from NDT proves to determine any structure failure and factors contribute to the problem. Furthermore, the solutions to the problem can be identified.
\end{abstract}

Keywords Non Destructive Test (NDT), Ultrasonic Pulse Velocity (UPV), X Ray Fluorescence (XRF), Carbonation

\section{Introduction}

Nondestructive test is a method of testing existing concrete structures to assess the strength and durability of concrete structure. In the nondestructive method of testing, without loading the specimen to failure (i.e., without destructing the concrete) we can measure the strength of concrete $[1,2]$. Nowadays this method has become a part of quality control process. This method of testing also helps us to investigate crack depth, micro cracks and deterioration of concrete. Nondestructive testing of concrete is a very simple method of testing but it requires skilled and experienced persons having some special knowledge to interpret and analyse test results. Various non-destructive methods of testing concrete have been developed to analyse properties of hardened concrete such as surface hardness test, rebound hammer test, penetration and pull-out techniques, dynamic or vibration test, $\mathrm{x}$ ray analysis and magnetic electrical method $[1,3]$.

Apart from that, Non-destructive testing (NDT) methods are techniques used to obtain information about the properties or internal condition of an object without damaging the object. Non-destructive testing is a descriptive term used to evaluate the materials and components in a way that protects materials from being destructive and can be used again for further investigation. In addition, NDT is a method of controlling the quality of 
the samples which can be extracted to performed a good management data analysis and helps to ensure a better understanding on the concrete quality. In order to achieve the goal, it requires an understanding of the various methods available, their capabilities and limitations, knowledge of the relevant standards and specifications for performing the tests. NDT techniques can be used to monitor the integrity of the item or structure throughout its design life $[4,5]$.

However, there is disadvantages on relying on NDT testing to confirm the health of concrete structures. To have an extensive finding it's important to performs a conventional methods of testing concrete such as in situ testing. Thus, coring of the samples for further testing to determine the strength and durability will be the priority [6]. Also, the test specimens are destroyed, once the test is performed and subsequent testing of the same specimens is not possible. Some of the important data such as curing effect, weathering action and time dependent behavior is not available. This will be the challenge on how to observed the concrete quality by using either NDT or destructive test [7]. The variability between the batches of concrete of the same mix proportion is assessed by testing test specimens under load in the laboratory. Such tests enable the variability of constituents of the mix to be controlled, but they cannot take into account the differences of compaction and actual curing conditions between the test specimens and the corresponding concrete in a structure [8]. It is these differences, which are difficult to assess by conventional strength tests. Also, conventional method of testing is not sufficient to predict the performance of the structures under adverse conditions such as exposure to liquid, gas, and chemicals radiation, explosion, fire, extreme cold or hot weather, marine and chemical environment. All such severe exposure conditions may induce deterioration in concrete and impair the integrity, strength and stability of the structure [9]. Thus, conventional strength test does not give idea about the durability and performance of the actual concrete in the structure. This gave the impetus to the development of non-destructive methods for testing structural concrete in-situ [10].

Thus, NDT methods are extremely valuable in assessing the condition of structures, such as bridges, buildings, elevated service reservoirs and highways etc. The principal objectives of the non-destructive testing of concrete in situ is to assess one or more of the following properties of structural concrete as below

- Strength properties at field condition

- Durability of concrete

- Density of concrete

- Moisture content of concrete

- Elastic properties of concrete

- Cracks at surface

- Concrete cover over the reinforcement.

In recent years, significant advances have been made in
Non-destructive Testing techniques, equipment and methods.

There are occasions when various performance characteristics of concrete in a structure are required to be assessed. In most of the cases, an estimate strength of concrete in the structure is needed although parameters like overall quality, uniformity etc., also become important. Various methods that can be adopted for in-situ assessment of strength properties of concrete depend upon the particular aspect of the strength in question.

Ultra sonic pulse velocity is one of the known NDT technique to measure the concrete quality. This is one of the most commonly used method in which the ultrasonic pulses generated by electro-acoustical transducer are transmitted through the concrete. In solids, the particles can oscillate along the direction of sound propagation as longitudinal waves or the oscillations can be perpendicular to the direction of sound waves as transverse waves. When the pulse is induced into the concrete from a transducer, it undergoes multiple reflections at the boundaries of the different material phases within the concrete $[11,12]$. A complex system of stress waves is developed which includes longitudinal (Compressional), shear (Transverse) and surface (Rayleigh) waves. These transducers convert electrical signals into mechanical vibrations (transmit mode) and mechanical vibration into electrical signals (receive mode). The travel time is measured with an accuracy of $+/-0.1$ microseconds. Transducers with natural frequencies between $20 \mathrm{kHz}$ and $200 \mathrm{kHz}$ are available, but $50 \mathrm{kHz}$ to $100 \mathrm{kHz}$ transducers are common $[13,14]$.

Pulse Velocity method is a convenient technique for investigating structural concrete. The underlying principle of assessing the quality of concrete is that comparative higher velocities are obtained when the quality of concrete in terms of density, homogeneity and uniformity is good. In case poorer quality of concrete, lower velocities are obtained. If there is a crack, void or flaw inside the concrete which comes in the way of transmission of the pulses, the pulse strength is attenuated and it passes around the discontinuity, thereby making path length longer. Consequently, lower velocities are obtained. The actual pulse velocity obtained depends primarily upon the material and the mix proportion of the concrete. Density and modulus of elasticity of aggregate also significantly affect the pulse velocity.

$\mathbf{X}$-ray fluorescence (XRF) is a method of determining the element of a material. The concept of XRF is by using secondary fluorescent $X$ rays and aligned with high energy $\mathrm{X}$ rays. In general, XRF is used to detect the elements for construction materials such as concrete, steel, pavement, glass and others. For concrete, major elements to be analysed is calcium, silica, alumina carbon, ferum and others. This is one of the important methods that can support the NDT test which can focus on the specific elements for every detail construction material [11]. 
Furthermore, those elements represent the concrete quality by identifying the development of binder, bonding and pores in the microstructure of concrete. This is one of the rapid methods to identify the concrete by applying the instruments to the surface of the sample [15].

Ground-penetrating radar (GPR) is a method that transmits radar signal pulse into image. It is an NDT testing, focusing on the detail embedded in the macrostructure of construction materials. GPR normally used in detection of underground utilities such as concrete, pavement and soil. The concept of GPR is the use of electromagnetic radiation in a microwave band with the aid of radio spectrum. The range of GPR range between $10 \mathrm{MHz}$ into $3 \mathrm{GHz}$. The low the amplitude or wave signal resulting in deeper analysis but low in imaging analysis. Thus, higher amplitude resulting good imaging analysis but the detection for depth analysis is limited. However, GPR signal is very sensitive to moisture. Moisture will make the signal lost and analysis aborted. GPR also has a limitation when contact with soil surface. This occurs due to moisture that will absorb the signal.

Rebound hammer is one of the NDT methods that can determine the compressive strength based on surface hardness analysis. Normally, the compressive strength taken by rebound hammer is taken at the concrete surface. To make the analysis precise, a grid needs to be prepared at the surface and point of rebound testing need to be done as much as can. This aims to ensure a more reliable data with related to strength. However, to confirm on the final compressive strength, the destructive compressive strength from core sample need to be done.

\section{Methodology}

Several testing are implemented in order to analyse structural integrity of targeted beams. Those were taken to ensure the credibility of the analysis of affected area. The quality of concrete is conducted using chemical compound test onto crack line to identify possible chemical elements which have potential in causing the occurrence of detected crack line on the surface (X-Ray Fluorescent Spectrometry). For XRF the standard practice is in accordance with ASTM E1621. Carbonation test were done on selected area on which crack line existed on the beams. Chemical analysis for $\mathrm{pH}$ and moisture test were taken as to further support carbonation test result. In the determination of carbonation using the rapid carbonation test kit, all the procedure is in accordance with UNI 9944:1992.

\section{Results and Discussion}

\section{Crack detection and UPV evaluation}

The quality of concrete beam named $3 \mathrm{~A}, 3 \mathrm{~B}$ and $4 \mathrm{~A}$ is portrait in Table 1 and Table 2. The result tabulated in Table 1 shows the quality of concrete is affected. This is supported by a diagonal crack at the surface of Beam 3B as shown in Figure 1 and by sketch in Figure 2. There are several factors that contributed to this defect. Poor workmanship from operator could be the cause of this problem. Insufficient bars during preparing beam, unskilled worker during concreting and lack of experience from junior construction practice are among the contributor of this problem. It is easy to find this defect especially after concreting that shows the sign of honeycomb and macro void from improper bonding between cement and aggregate [1, 16, 17]. This outcome is supported by the crack analysis using crack ruler scale shown in Table 2. Beam $3 \mathrm{~A}$ as referred to Figure 3 and Figure 4 and Beam 3B as referred in Figure 5 and Figure 6 recorded crack width marked at $10 \mathrm{~mm}$ to $20 \mathrm{~mm}$ and shown in Figure 7 and 8 respectively. However, in Figure 9 and Figure 10, Beam 4A shows a smaller crack width which is $10 \mathrm{~mm}$; and this finding supported the good quality performed by UPV result, which is confirmed by sketch in Figure 11 and 12. Further explanation is supported by the result of carbonation, $\mathrm{pH}$ meter and moisture meter taken at the surface of 3 beams. It shows that from three beams, beam $3 \mathrm{~B}$ shown in Figure 5 is recorded with high carbonation rate more than $30 \%$. For beam $3 \mathrm{~A}$ and $4 \mathrm{~A}$ shown in Figure 1 and Figure 9, the carbonation rate is less than $20 \%$ and this is supported with reasonable value from $\mathrm{pH}$ meter and moisture meter. This confirms that the quality of Beam $3 \mathrm{~B}$ is already affected, reducing the performance of concrete. The high carbonation values may come from improper selection of raw material such as aggregate. However, the potential of the carbonation occurs could be from the external effect such as surrounding. The reason is that the building is located near to seashore. The potential of carbonation and corrosion could occur [18-20]. A combination of external effects from sea which a potential to sulfate is promoted to the lowering the integrity of beam $3 \mathrm{~B}$ as compared to the other beam $3 \mathrm{~A}$ and $4 \mathrm{~A}$ respectively.

Table 1. Ultrasonic pulse velocity result for targeted beam

\begin{tabular}{|c|c|c|}
\hline Beam & UPV $(\mathbf{k m} / \mathbf{s})$ & Result \\
\hline Beam 3A & 4.2 & Good \\
\hline Beam 3B & 2.2 & Poor \\
\hline Beam 4A & 4.2 & Good \\
\hline
\end{tabular}


Table 2. Crack, carbonation, $\mathrm{pH}$ and moisture analysis

\begin{tabular}{|c|c|c|c|c|c|c|c|}
\hline \multirow{3}{*}{ No. } & \multirow{3}{*}{ Grid point } & \multicolumn{5}{|c|}{ Testing Method } & \multirow{3}{*}{ Remark } \\
\hline & & \multicolumn{2}{|c|}{ Crack Measurement } & \multirow{2}{*}{$\begin{array}{l}\text { Carbonation } \\
\text { rate }(\%)\end{array}$} & \multirow{2}{*}{ pH meter } & \multirow{2}{*}{$\begin{array}{l}\text { Moisture } \\
\text { Meter }\end{array}$} & \\
\hline & & Width (mm) & & & & & \\
\hline 1 & $3 \mathrm{~A} 1-4$ & 0.20 & & 16.95 & & 15.1 & \\
\hline 2 & $3 \mathrm{~A} 2-3$ & 0.20 & \multirow{4}{*}{$20.0+/-3.0$} & & & & \\
\hline 3 & $3 \mathrm{~A} 2-4$ & 0.20 & & & & & \\
\hline 4 & $3 \mathrm{~A} 2-5$ & 0.25 & & & & & \multirow{2}{*}{$\begin{array}{l}\text { UPV test had been } \\
\text { done }\end{array}$} \\
\hline 5 & $3 \mathrm{~A} 2-6$ & 0.25 & & & & & \\
\hline 6 & $3 \mathrm{~A} 4-3$ & 0.25 & \multirow{4}{*}{$10.0+/-3.0$} & & & & \\
\hline 7 & $3 \mathrm{~A} 4-4$ & 0.30 & & & & & \\
\hline 8 & $3 \mathrm{~A} 4-5$ & 0.20 & & & & & \\
\hline 9 & $3 \mathrm{~A} 4-6$ & 0.20 & & 19.62 & 10.35 & 13.7 & \\
\hline 10 & $3 \mathrm{~A} 5-3$ & 0.30 & \multirow{3}{*}{$20.0+/-3.0$} & & & & \\
\hline 11 & $3 \mathrm{~A} 5-4$ & 0.30 & & & & & \\
\hline 12 & $3 \mathrm{~A} 5-6$ & 0.25 & & & & & \\
\hline 13 & $3 \mathrm{~B} 2-1$ & 0.30 & \multirow{5}{*}{$20.0+/-3.0$} & & & & \multirow{5}{*}{$\begin{array}{c}\text { Potential of } \\
\text { carbonation effect } \\
\text { (UPV test had been } \\
\text { done) }\end{array}$} \\
\hline 14 & $3 B 2-2$ & 0.35 & & & & & \\
\hline 15 & $3 \mathrm{~B} 2-3$ & 0.40 & & & & & \\
\hline 16 & $3 B 2-4$ & 0.30 & & 32.05 & 10.32 & 14.8 & \\
\hline 17 & $3 \mathrm{~B} 2-5$ & 0.25 & & & & & \\
\hline 18 & 3B3-1 & 0.20 & \multirow{4}{*}{$10.0+/-3.0$} & & & & \multirow{4}{*}{$\begin{array}{c}\text { Potential of } \\
\text { carbonation effect }\end{array}$} \\
\hline 19 & $3 B 3-2$ & 0.25 & & & & & \\
\hline 20 & 3B3-3 & 0.45 & & 37.86 & 10.88 & 16.5 & \\
\hline 21 & $3 B 3-4$ & 0.40 & & & & & \\
\hline 22 & $4 \mathrm{~A} 1-1$ & 0.25 & \multirow{3}{*}{$10.0+/-3.0$} & & & & \\
\hline 23 & $4 \mathrm{~A} 1-3$ & 0.30 & & & & & \\
\hline 24 & $4 A 1-4$ & 0.25 & & & & & \\
\hline 25 & $4 \mathrm{~A} 1-\mathrm{A} 1-3$ & 0.10 & & & & & \\
\hline 26 & $4 \mathrm{~A} 2-2$ & 0.25 & \multirow{3}{*}{$10.0+/-3.0$} & 24.86 & 10.99 & 16.5 & \\
\hline 27 & $4 \mathrm{~A} 2-3$ & 0.35 & & & & & \\
\hline 28 & $4 A 2-4$ & 0.35 & & & & & \\
\hline 29 & $4 \mathrm{~A} 3$ & & & 15.86 & 10.70 & 16.5 & \\
\hline
\end{tabular}




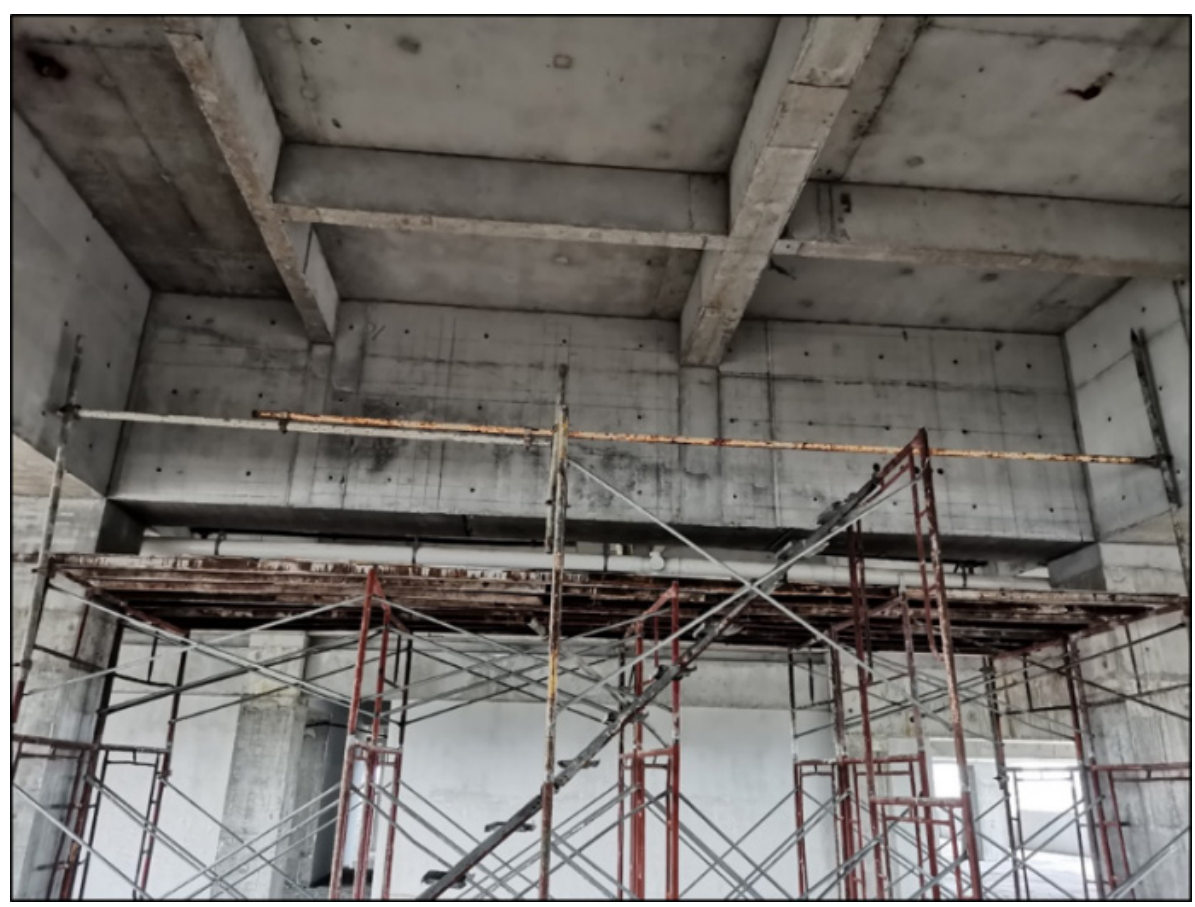

Figure 1. Beam $3 \mathrm{~A}$

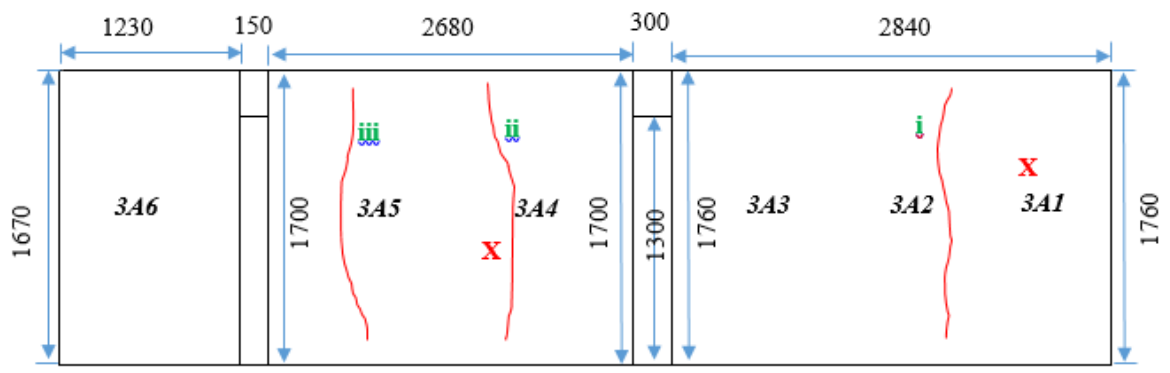

Note: $\mathrm{X}=$ carbonation and $\mathrm{pH}$ sample point

Figure 2. Location of identified cracks on measured beam

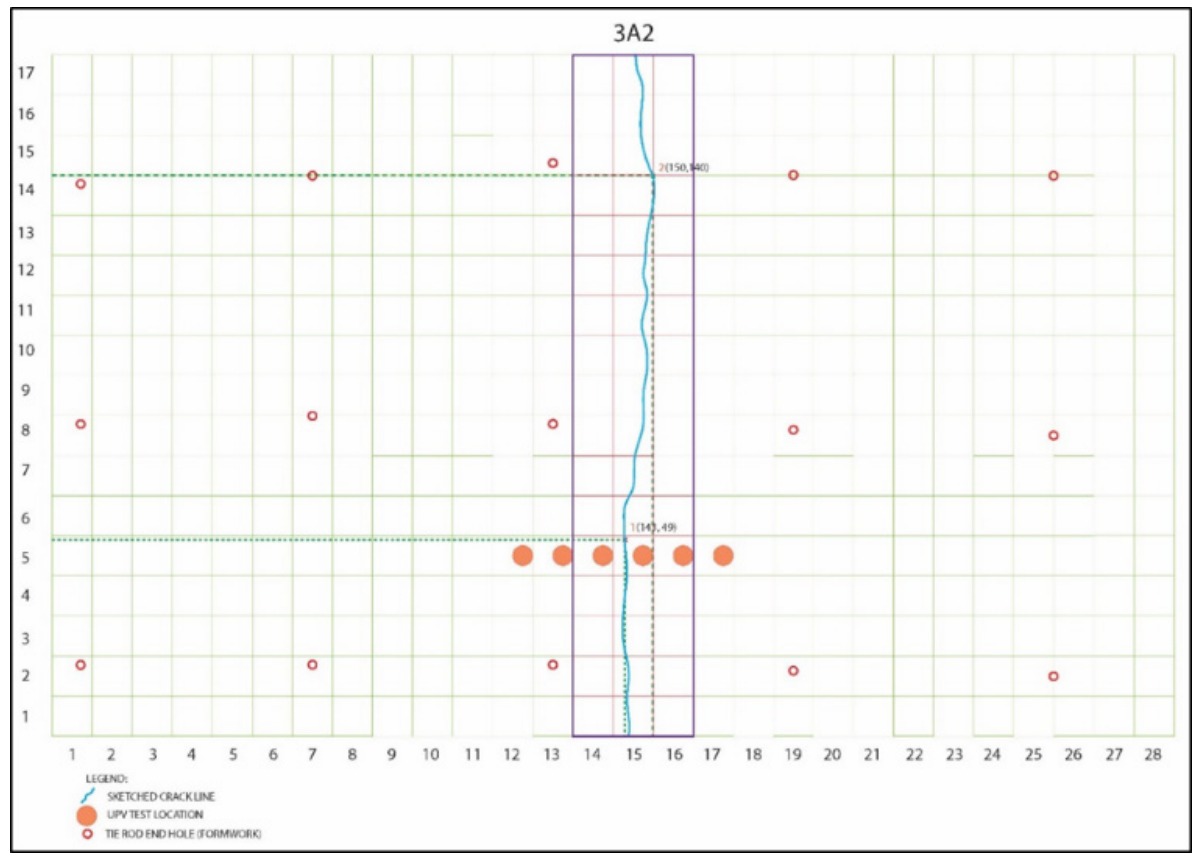

Figure 3. Location of crack at $3 \mathrm{~A} 2$ on the grid line 


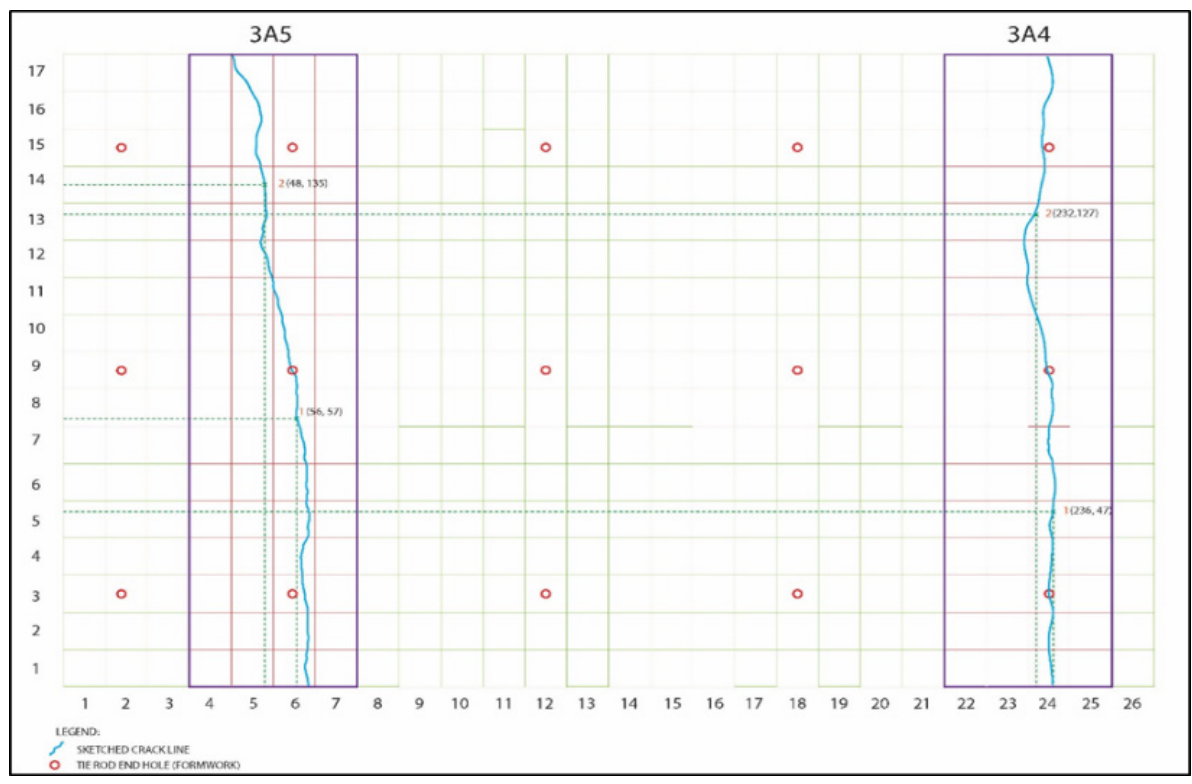

Figure 4. Location of crack at $3 \mathrm{~A} 4$ and $3 \mathrm{~A} 5$ on the grid line

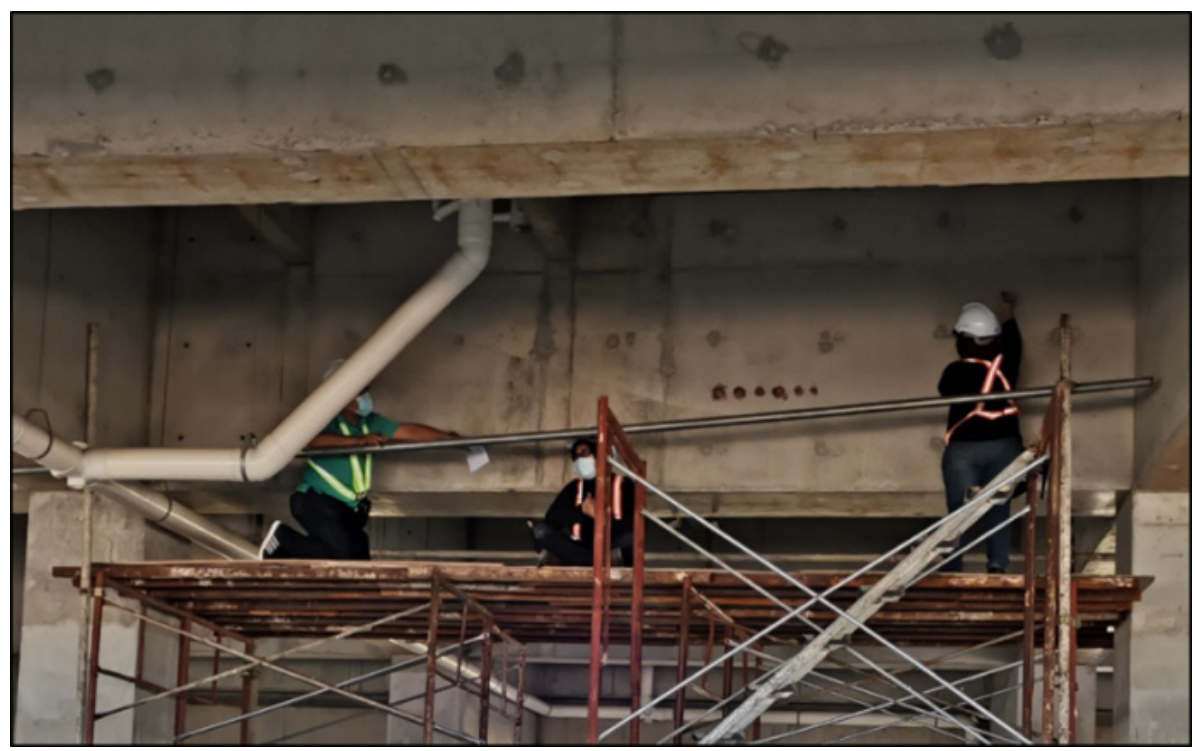

Figure 5. Location for Beam 3B

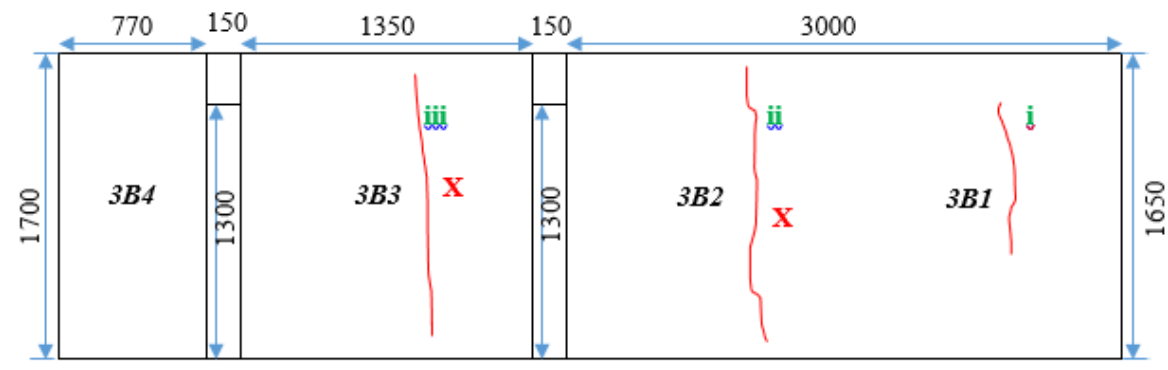

Note: $\mathrm{X}=$ carbonation and $\mathrm{pH}$ sample point 
Figure 6. Location of identified cracks on measured beam

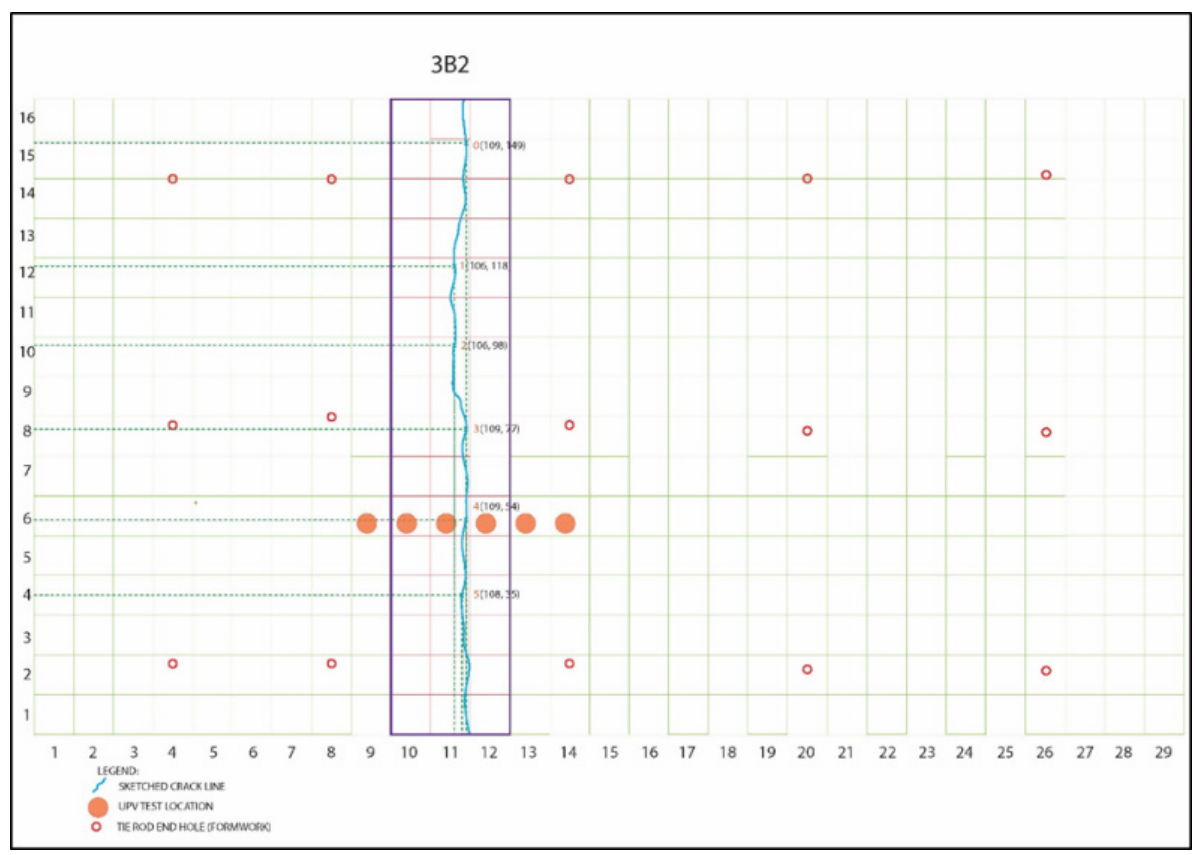

Figure 7. Location of crack at $3 \mathrm{~B} 2$ on the grid line

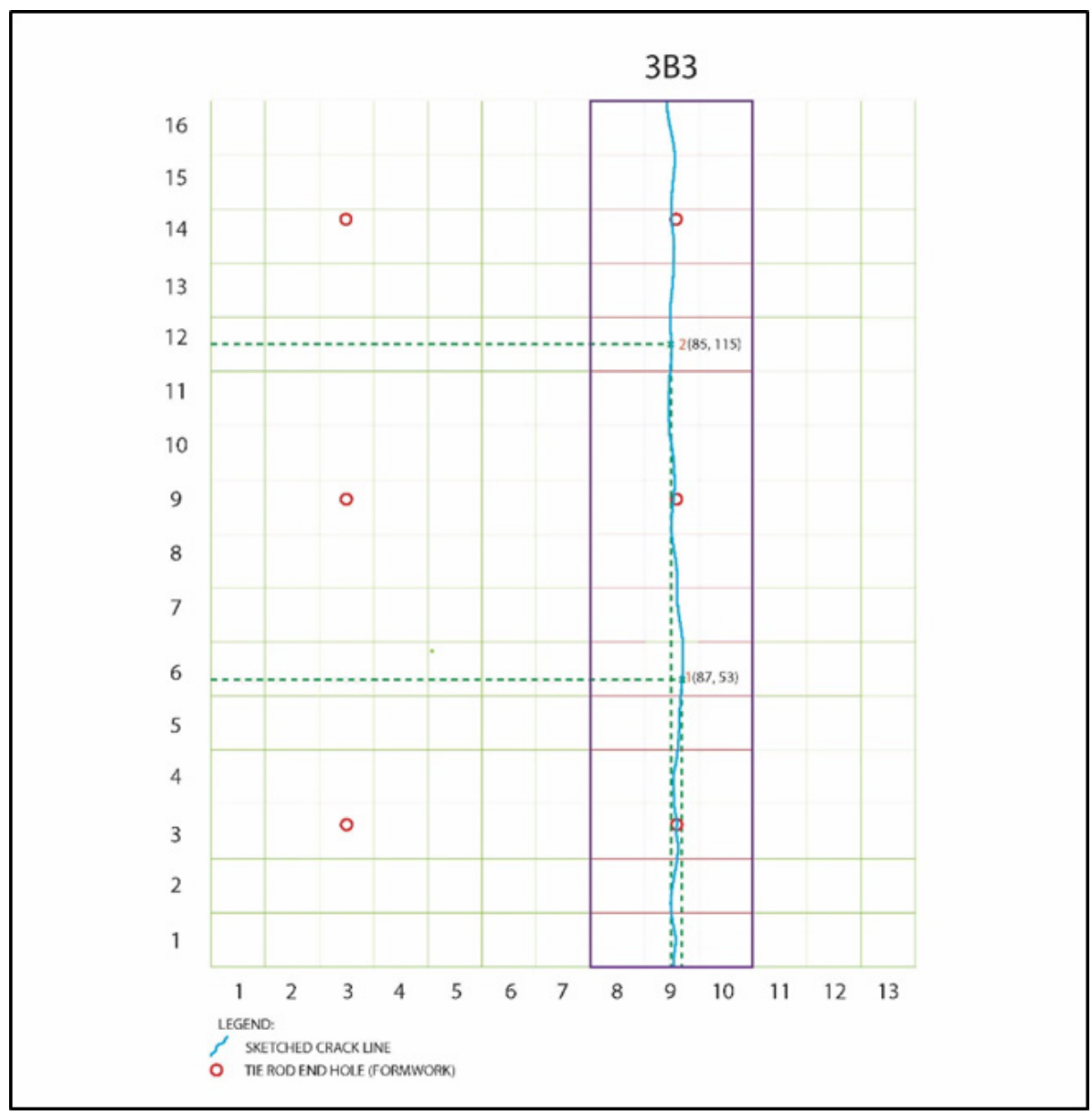

Figure 8. Location of crack at $3 \mathrm{~B} 3$ on the grid line 


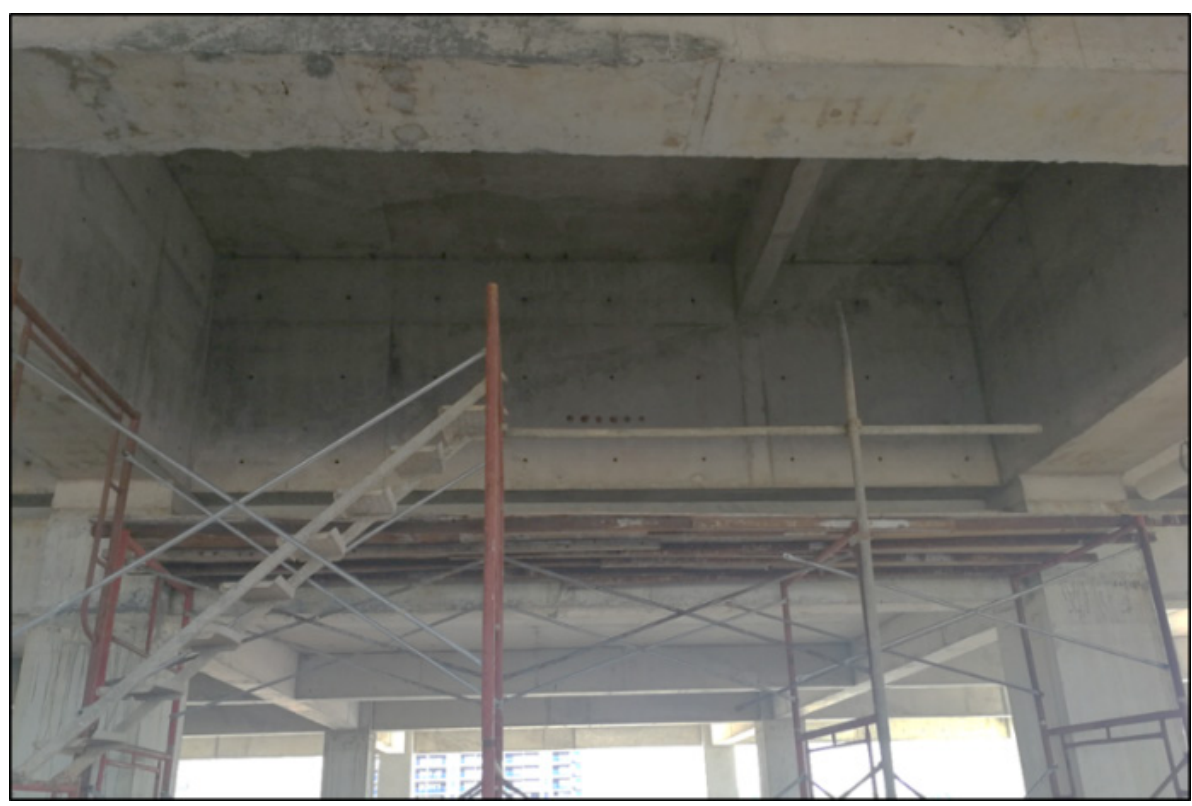

Figure 9. Location of Beam 4A

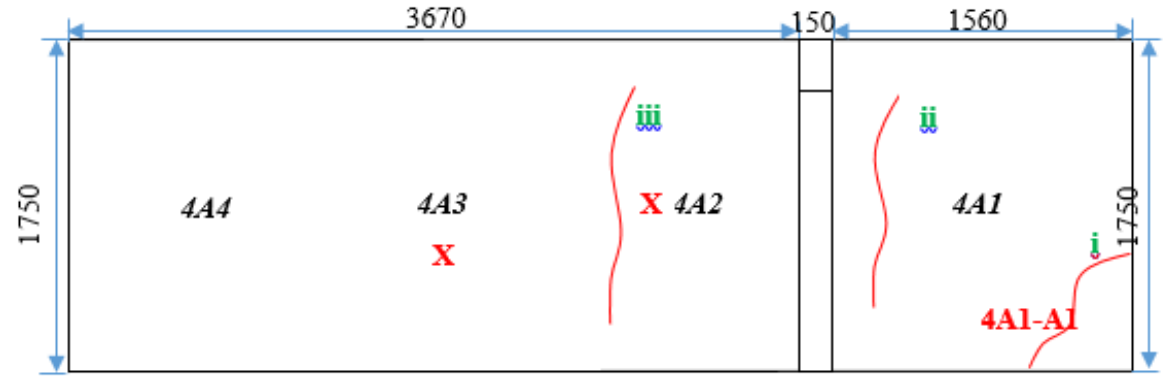

Note: $\mathrm{X}=$ carbonation and $\mathrm{pH}$ sample point

Figure 10. Location of identified cracks on measured beam 


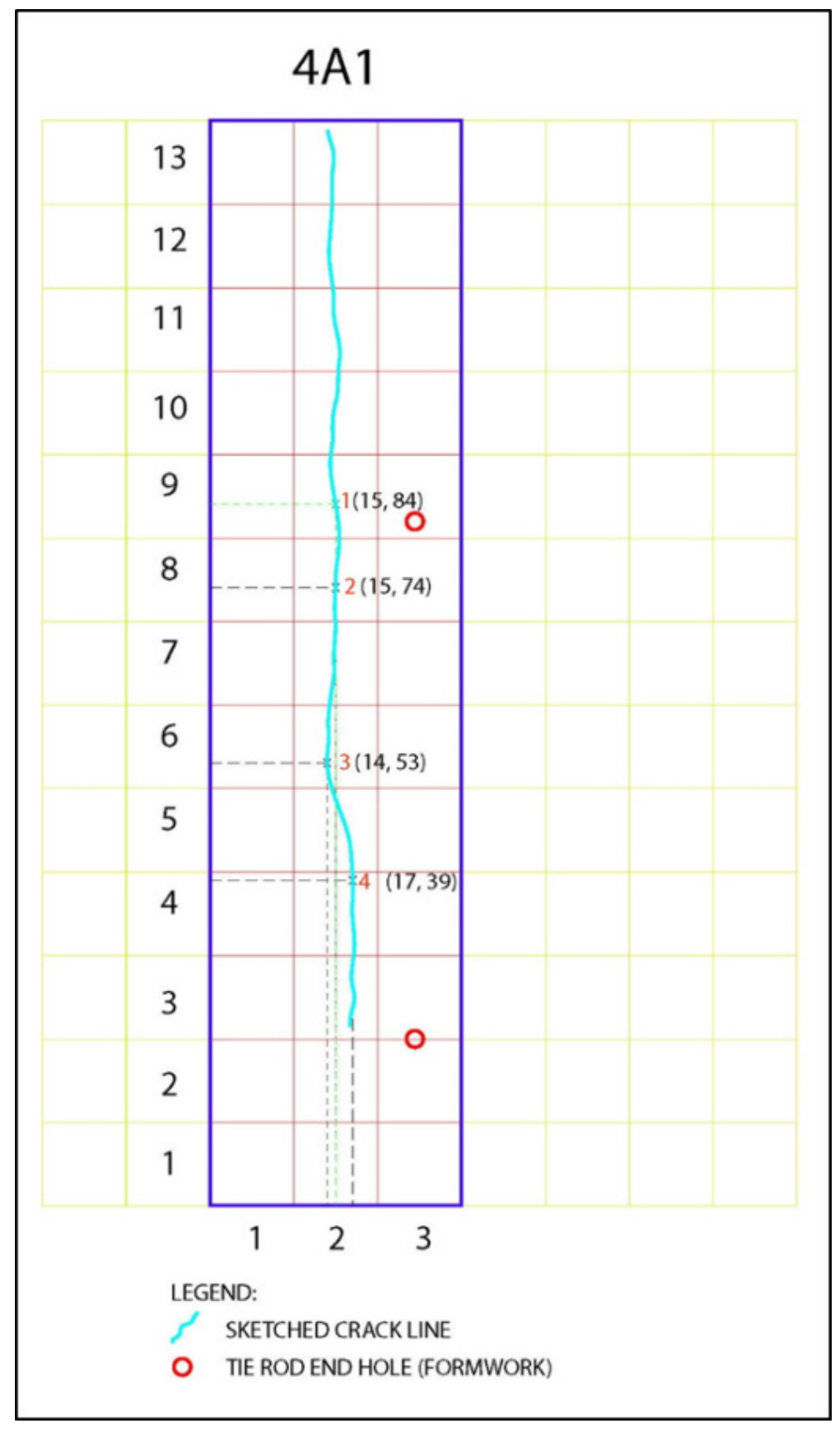

Figure 11. Location of crack at $4 \mathrm{~A} 1$ on the grid line 


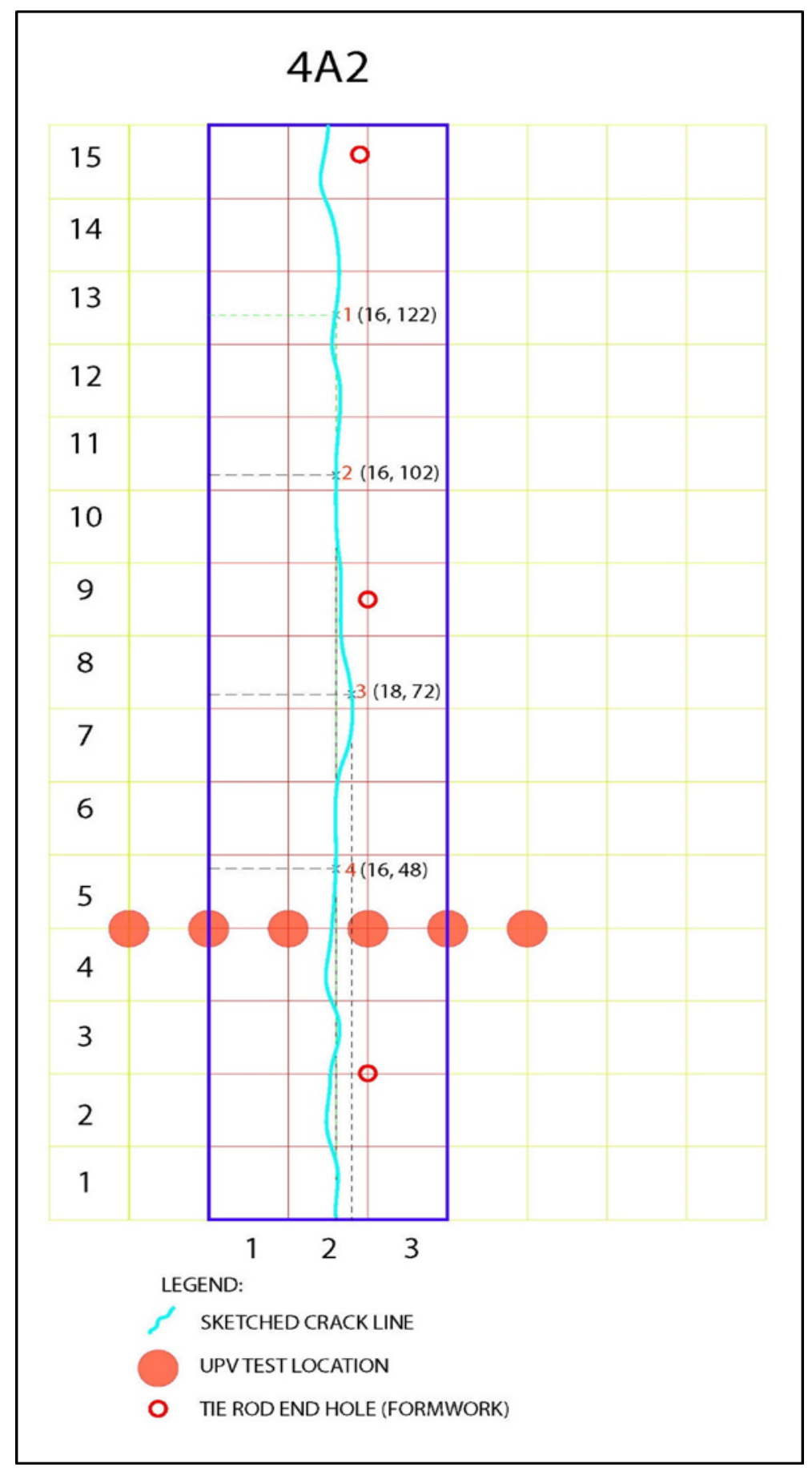

Figure 12. Location of crack at $4 \mathrm{~A} 2$ on the grid line

\section{Chemical analysis}

The performance of beam $3 \mathrm{~A}, 3 \mathrm{~B}$ and $4 \mathrm{~A}$ is supported by chemical analysis using portable XRF analysis at the surface of concrete beam and the data is tabulated in Table 3. Six elements to be highlighted are Calcium Oxide which influenced the binding of the concrete, Aluminium Oxide, which aims to see the setting time ability of the concrete beam either still setting or not, Silica Oxide on the strength enhancement of concrete, Sulphur Oxide, Iron
Oxide and Magnesium Oxide on the durability aspect especially dealing with corrosion. Surprisingly, from this chemical analysis which is taken from the crack surface for every beam, shows that Beam 3B shows a moderate affected by those elements as mentioned earlier as compared to Beam 3A and 4A. From this finding, it is confirmed that the concrete for beam $3 \mathrm{~B}$ is consistent in terms of concrete quality. This is supported by consistent elements of Calcium Oxide, Alumunium Oxide and Silica Oxide. Based on the design provided by consultant, those 
elements detected is similar to the concrete grade 40 . From this, the defect detected for beam 3B is not attributed to the insufficient concrete grade. So most probably the crack detected and followed by poor UPV result is attributed to environmental effect or maybe result from poor workmanship during construction. The durability aspect of beam 3B also is not severely affected due to the elements of Sulphur, Iron and Magnesium Oxides which is moderate as mentioned by normal grade 40 for concrete [21-23]. For beam 3A the quality of concrete in terms of binder and strength is moderate from the reading of Calcium, Aluminium and Silica Oxides. However, other elements such as Sulphur, Iron and Magnesium is detected higher than beam 3B. This can be seen from the high elements detected in beam $3 \mathrm{~A}$ which is
Sulphur and Iron which is more than 5\% as mentioned from previous researchers [24-26]. These two items will affect the durability of concrete by promoting corrosion to the reinforcement bars in the future. This is supported by high element of Iron oxide in beam 3A as shown in Table 3. As for beam $4 \mathrm{~A}$, the concrete quality is doubtful base on the inconsistency of the calcium, aluminium and silica elements detected in the beam. This could be one of the factors that can reduce the lifetime of concrete in the future. The amount of sulphur and iron is detected higher as compared to beam $3 \mathrm{~A}$ and $3 \mathrm{~B}$. This factor contributed to these other that been mentioned earlier because of the environmental effect such as sulfate environment which was located near to marine or offshore condition [27-29].

Table 3. Elementary analysis for targeted structure

\begin{tabular}{|c|c|c|c|c|c|c|c|c|}
\hline \multirow[b]{2}{*}{ No. } & \multirow[b]{2}{*}{$\begin{array}{l}\text { Grid } \\
\text { point }\end{array}$} & \multicolumn{6}{|c|}{ XRF Chemical Element (\%) } & \multirow[b]{2}{*}{ Remarks } \\
\hline & & $\begin{array}{c}\text { Calcium } \\
\text { oxide, } \\
\text { CaO }\end{array}$ & $\begin{array}{l}\text { Aluminium } \\
\text { oxide, } \mathrm{Al}_{2} \mathrm{O}_{3}\end{array}$ & $\begin{array}{c}\text { Silica } \\
\text { oxide, } \\
\mathrm{SiO}_{2}\end{array}$ & $\begin{array}{c}\text { Sulphur } \\
\text { oxide, } \mathrm{SO}_{3}\end{array}$ & $\begin{array}{c}\text { Iron oxide, } \\
\mathrm{Fe}_{2} \mathrm{O}_{3}\end{array}$ & $\begin{array}{c}\text { Magnesiu } \\
\text { m oxide, } \\
\text { MgO } \\
\end{array}$ & \\
\hline 1 & $3 \mathrm{~A} 1-4$ & 55.9442 & 8.2868 & 26.9941 & 1.3782 & 5.0014 & $<\mathrm{LOD}$ & Fair \\
\hline 2 & $3 \mathrm{~A} 2-3$ & 54.8872 & 8.4967 & 25.2795 & 1.3037 & 5.1373 & 2.4055 & Moderate \\
\hline 3 & $3 \mathrm{~A} 2-4$ & 49.4305 & 8.6828 & 31.5437 & 3.0311 & 4.7146 & $<$ LOD & $\begin{array}{l}\text { Moderate (High } \\
\text { sulphur content) }\end{array}$ \\
\hline 4 & $3 \mathrm{~A} 2-5$ & 56.6584 & 8.3710 & 24.5964 & 1.3694 & 5.0350 & 1.5754 & \multirow{2}{*}{ Moderate } \\
\hline 5 & $3 A 2-6$ & 58.7496 & 7.9882 & 22.2223 & 1.4557 & 5.2224 & 1.8298 & \\
\hline 6 & $3 \mathrm{~A} 4-3$ & 55.3859 & 7.2461 & 23.0466 & 5.0842 & 5.1802 & 1.7760 & $\begin{array}{l}\text { Moderate (High } \\
\text { sulphur content) }\end{array}$ \\
\hline 7 & $3 \mathrm{~A} 4-4$ & 50.3861 & 8.1342 & 29.9655 & 2.7650 & 4.9706 & 1.5679 & Fair \\
\hline 8 & 3A4-5 & 60.6735 & 6.7601 & 20.1153 & 4.0945 & 5.5648 & $<\mathrm{LOD}$ & \multirow{2}{*}{$\begin{array}{l}\text { Moderate (High } \\
\text { sulphur content) }\end{array}$} \\
\hline 9 & 3A4-6 & 59.2491 & 4.7160 & 20.3081 & 8.1670 & 5.1707 & $<$ LOD & \\
\hline 10 & 3 A5-3 & 56.5401 & 6.9671 & 23.7653 & 3.1995 & 5.2664 & 2.0121 & \multirow{3}{*}{$\begin{array}{l}\text { Moderate (High } \\
\text { sulphur content) } \\
\text { Discoloration } \\
\text { detected } \\
\end{array}$} \\
\hline 11 & $3 \mathrm{~A} 5-4$ & 59.5346 & 6.1741 & 21.2495 & 3.9837 & 5.0441 & 1.8596 & \\
\hline 12 & 3 A5-6 & 60.8043 & 4.6560 & 19.4238 & 7.7710 & 4.8214 & 0.8763 & \\
\hline 13 & $3 \mathrm{~B} 2-1$ & 54.9052 & 8.3253 & 26.5294 & 1.2781 & 4.8746 & 1.4462 & \multirow{5}{*}{ Moderate } \\
\hline 14 & $3 \mathrm{~B} 2-2$ & 54.6850 & 7.1299 & 26.8318 & 2.4433 & 4.6961 & 2.1369 & \\
\hline 15 & $3 B 2-3$ & 54.6631 & 7.4377 & 26.6373 & 2.2958 & 4.6865 & 2.0850 & \\
\hline 16 & $3 B 2-4$ & 51.0970 & 7.4077 & 30.5151 & 2.5835 & 4.6165 & 1.7925 & \\
\hline 17 & $3 B 2-5$ & 56.9420 & 6.5257 & 25.6079 & 1.9329 & 4.3993 & 2.5908 & \\
\hline 18 & 3B3-1 & 65.2748 & 5.8677 & 20.8936 & 0.4365 & 5.1909 & $<$ LOD & \multirow{4}{*}{ Moderate } \\
\hline 19 & 3B3-2 & 55.4166 & 6.8492 & 25.5286 & 3.0500 & 4.9451 & 1.9598 & \\
\hline 20 & 3B3-3 & 55.6366 & 6.7134 & 25.2674 & 2.6305 & 4.3505 & 3.2968 & \\
\hline 21 & $3 B 3-4$ & 61.2841 & 6.7931 & 21.0502 & 1.8643 & 4.7914 & 1.8988 & \\
\hline 22 & 4A1-1 & 50.3823 & 8.6243 & 26.9968 & 1.5713 & 6.1012 & 3.4479 & Fair \\
\hline 23 & 4A1-3 & 65.9779 & 6.4244 & 15.0966 & 0.0933 & 7.4707 & 1.9548 & $\begin{array}{c}\text { Moderate } \\
\text { (low silica, high iron } \\
\text { content) }\end{array}$ \\
\hline 24 & 4A1-4 & 51.7020 & 9.0399 & 23.2669 & 1.7382 & 6.9605 & 3.9999 & Fair \\
\hline 25 & $\begin{array}{c}4 \mathrm{~A} 1-\mathrm{A} \\
1-3\end{array}$ & 40.7998 & 12.5873 & 30.4453 & 0.1658 & 8.2244 & 3.2503 & $\begin{array}{c}\text { Moderate } \\
\text { (High iron, alumina } \\
\text { and silica with } \\
\text { reduced calcium) }\end{array}$ \\
\hline 26 & $4 \mathrm{~A} 2-2$ & 66.3363 & 5.7859 & 10.2199 & 6.3866 & 7.6093 & $<\mathrm{LOD}$ & $\begin{array}{l}\text { Moderate (High } \\
\text { Sulphur content) }\end{array}$ \\
\hline 27 & $4 \mathrm{~A} 2-3$ & 57.3184 & 8.4880 & 18.3637 & 2.0490 & 6.5737 & 3.8506 & Fair \\
\hline 28 & $4 \mathrm{~A} 2-4$ & 54.2545 & 7.7214 & 21.6178 & 3.4031 & 6.4683 & 3.6261 & $\begin{array}{l}\text { Moderate (High } \\
\text { sulphur content) }\end{array}$ \\
\hline 29 & $4 \mathrm{~A} 3$ & 52.5671 & 8.1218 & 24.2160 & 2.4718 & 6.6900 & 2.8344 & Fair \\
\hline 30 & $4 \mathrm{~A} 4$ & 73.3684 & 6.1742 & 6.1688 & 1.7202 & 8.3191 & $<\mathrm{LOD}$ & $\begin{array}{c}\text { Moderate (High } \\
\text { calcium, low silica) }\end{array}$ \\
\hline
\end{tabular}

Note: * Each color represents one straight crack line or area 


\section{Conclusions}

From this report, the conclusions can be drawn as follows:

1. For Beam $3 \mathrm{~A}$, the concrete quality is considered, as fair and strength of concrete is in targeted strength between concrete grade 35 to $45 \mathrm{MPa}$ (need to confirm from design mix). This is confirmed from the consistent reading of calcium, silica and alumina from elementary analysis. However, several numbers of crack have been identified as stated in Table 2 and need to further check. Furthermore, a minimum carbonation effect has been detected but the reading is considered as low and should not affected the performance of concrete.

2. For Beam 3B, the performance and strength of concrete is considered moderate and doubtful. This is confirmed due to high carbonation reading taken from the beam. The possibility of this occurred because of selection of material or design which need further check.

3. For Beam 4A, the concrete beam is considered as fair and similar to Beam $3 \mathrm{~A}$. However, the reading for elementary analysis is detected not consistent and discoloration at the surface of concrete. Prior to that, the selection of material may contribute to the problem as stated.

\section{Acknowledgements}

Researchers are gratitude for the commitment from all staff Institute for Infrastructure Engineering and Sustainable Management (IIESM) during the inspection and report, last but not least, to Mr Ir Dzulkafley Abdul Samad for sharing idea and knowledge during this inspection.

\section{REFERENCES}

[1] Y. El Masri and T. Rakha, "A scoping review of non-destructive testing (NDT) techniques in building performance diagnostic inspections," Constr Build Mater, vol. 265, p. 120542, 2020/12/30/ 2020, doi: https://doi.org/10.1016/j.conbuildmat.2020.120542.

[2] R. Corral, S. P. Arredondo, J. M. Gómez, D. C. Gámez, J. M. Mendivil, and J. L. Almaral, "Strength and durability parameters of an environmentally friendly concrete," in 12th International Conference on Recent Advances in Concrete Technology and Sustainability Issues 2012, Prague, 2012, 289 SP ed., pp. 229-243. [Online]. Available: https://www.scopus.com/inward/record.uri?eid=2-s2.0-848 75762512\&partnerID $=40 \& \mathrm{md} 5=$ f26a6f8afcb546246a3f95 4dad27298d. [Online]. Available: https://www.scopus.com/inward/record.uri?eid=2-s2.0-848 75762512\&partnerID $=40 \& m d 5=f 26 a 6 f 8 a f c b 546246 a 3 f 95$ 4dad27298d

[3] K. E. Ridgley, A. A. Abouhussien, A. A. A. Hassan, and B Colbourne, "Characterisation of damage due to abrasion in SCC by acoustic emission analysis," (in English), Mag Concr Res, Article vol. 71, no. 2, pp. 85-94, 2019, doi: 10.1680/jmacr.17.00445.

[4] H. Kim, D. Kang, S. J. Oh, and C. Joo, "Nondestructive evaluation on dispersion of steel fibers in UHPC using THz electromagnetic waves," (in English), Constr Build Mater, Article vol. 172, pp. 293-299, 2018, doi: 10.1016/j.conbuildmat.2018.03.238.

[5] A. Joshaghani and D. G. Zollinger, "Concrete pavements curing evaluation with non-destructive tests," Constr Build Mater, vol. 154, pp. 1250-1262, 2017/11/15/ 2017, doi: https://doi.org/10.1016/j.conbuildmat.2017.06.110.

[6] R. R. Ruiz, E. M. A. Guzmán, W. M. Molina, H. L. C. García, and J. A. V. Perez. Non-destructive tests as durability indicators in cement mortars with pozzolanic substitutions, International Conference on Civil and Building Materials, ICCBM 2016, vol. 902 MSF, pp. 9-13, 2017.

[7] O. Tsioulou, A. Lampropoulos, and S. Paschalis, "Combined Non-Destructive Testing (NDT) method for the evaluation of the mechanical characteristics of Ultra High Performance Fibre Reinforced Concrete (UHPFRC)," (in English), Constr Build Mater, Article vol. 131, pp. 66-77, 2017, doi: 10.1016/j.conbuildmat.2016.11.068.

[8] D. Y. Yoo, H. O. Shin, and Y. S. Yoon, "Ultrasonic monitoring of setting and strength development of ultra-high-performance concrete," (in English), Mater., Article vol. 9, no. 4, 2016, Art no. 294, doi: 10.3390/ma9040294.

[9] A. M. Neville, Properties of Concrete, 5th ed. England: Prentice Hall, 2005, p. 844.

[10] I. Taraghi and A. Fereidoon, "Non-destructive evaluation of damage modes in nanocomposite foam-core sandwich panel subjected to low-velocity impact," Compos Part B: Eng, vol. 103, pp. 51-59, 2016/10/15/ 2016, doi: https://doi.org/10.1016/j.compositesb.2016.08.009.

[11] S. H. Sanni and R. B. Khadiranaikar, "Non Destructive Tests with Rebound Hammer and Ultrasonic Pulse Velocity Measurements on Geopolymer Concrete," (in English), Intl. J. Earth Sci. Eng., Article vol. 7, no. 1, pp. 331-335, 2014. [Online].

Available: https://www.scopus.com/inward/record.uri?eid=2-s2.0-849 05019279\&partnerID $=40 \& \mathrm{md} 5=\mathrm{aa} 67 \mathrm{a} 08 \mathrm{c} 1 \mathrm{~b} 832217 \mathrm{dcbe} 9$ 0b99f3b1056.

[12] V. Kannan, "Relationship between ultrasonic pulse velocity and compressive strength of self compacting concrete incorporate rice husk ash and metakaolin," (in English), Asian J. Civ. Eng., Article vol. 16, no. 8, pp. 1077-1088, 2015. [Online]. Available: https://www.scopus.com/inward/record.uri?eid=2-s2.0-849 $37407824 \&$ partnerID $=40 \&$ md5 $=0 \mathrm{c} 8780 \mathrm{~b} 75 \mathrm{~b} 97 \mathrm{~cd} 2677076$ $1 \mathrm{f} 51 \mathrm{c} 663 \mathrm{bca}$.

[13] H. M. Owaid, Z. A. S. Ghali, and S. A. Ali Dawood, "Compressive strength, ultrasonic pulse velocity and transport properties of self-compacting high performance concrete made with iraqi metakaolin," (in English), Int.J. 
Civ. Eng. Technol., Article vol. 9, no. 7, pp. 31-44, 2018. [Online]. Available: https://www.scopus.com/inward/recor d.uri?eid=2-s2.0-85052020735\&partnerID $=40 \& \mathrm{md} 5=7 \mathrm{abc}$ 753 ccec8faae 5 de 279 eb84c93046.

[14] Z. Yahya, M. M. A. B. Abdullah, N. Mohd Ramli, D. D. Burduhos-Nergis, and R. Abd Razak, "Influence of Kaolin in Fly Ash Based Geopolymer Concrete: Destructive and Non-Destructive Testing," in 2018 EUROINVENT International Conference on Innovative Research, EUROINVENT ICIR 2018, A. V. Sandu, I. Sandu, M. M. A. B. Abdullah, P. Vizureanu, and C. M. R. Ghazali, Eds., 2018, vol. 374: Institute of Physics Publishing, 1 ed., doi: 10.1088/1757-899X/374/1/012068. [Online]. Available: https://www.scopus.com/inward/record.uri?eid=2-s2.0-850 $49221237 \&$ doi $=10.1088 \% 2 \mathrm{f} 1757-899 \mathrm{X} \% 2 \mathrm{f3} 74 \% 2 \mathrm{fl} \% 2 \mathrm{f0}$ 12068\&partnerID $=40 \& \mathrm{md} 5=3 \mathrm{~b} 5 \mathrm{a} 8 \mathrm{cb} 6 \mathrm{e} 7 \mathrm{f} 750 \mathrm{~b} 407 \mathrm{~d} 70 \mathrm{ee} 7$ 97 dac292

[15] S. N. Iliopoulos et al., "Effective combination of DIC, AE, and UPV nondestructive techniques on a scaled model of the Belgian nuclear waste container," in Proceedings of SPIE - The International Society for Optical Engineering, 2015, vol. 9436, doi: 10.1117/12.2084189. [Online]. Available:

https://www.scopus.com/inward/record.uri?eid=2-s2.0-849 $43388968 \&$ doi $=10.1117 \% 2 \mathrm{f} 12.2084189$ \& partnerID $=40 \&$ $\mathrm{md} 5=\mathrm{f} 57 \mathrm{bc} 3 \mathrm{fd} 21 \mathrm{fe} 835412 \mathrm{e} 5 \mathrm{f} 103 \mathrm{f} 4 \mathrm{fa} 36 \mathrm{c} 0$

[16] R. Rodrigues, S. Gaboreau, J. Gance, I. Ignatiadis, and S. Betelu, "Reinforced concrete structures: A review of corrosion mechanisms and advances in electrical methods for corrosion monitoring," Constr Build Mater, p. 121240, 2020/10/26/ 2020, doi: https://doi.org/10.1016/j.conbuildm at.2020.121240.

[17] A. A. Abouhussien and A. A. A. Hassan, "Monitoring early age strength gain of SCC with different supplementary cementitious materials using acoustic emission sensors," (in English), Constr Build Mater, Article vol. 229, 2019, Art no. 116858, doi: 10.1016/j.conbuildmat.2019.116858.

[18] N. Gowripalan. Autogenous Shrinkage of Concrete at Early Ages, Lecture Notes in Civil Engineering, vol. 37, pp. 269-276, 2020.

[19] U. Raghu Babu and B. Kondraivendhan, "Corrosion performance of steel reinforcement in concrete admixed with magnesium chloride and sulphate," (in English), Anti-Corros. Methods Mater., Article vol. 67, no. 1, pp. 106-118, 2020, doi: 10.1108/ACMM-08-2019-2163.

[20] Z. Sun, A. Vollpracht, and H. A. van der Sloot, "pH dependent leaching characterization of major and trace elements from fly ash and metakaolin geopolymers," (in English), Cem Concr Res, Article vol. 125, 2019, Art no. 105889, doi: 10.1016/j.cemconres.2019.105889.

[21] V. Matte and M. Moranville, "Durability of reactive powder composites: influence of silica fume on the leaching properties of very low water/binder pastes," Cem Concr Compos, vol. 21, no. 1, pp. 1-9, // 1999, doi: http://dx.doi.org/10.1016/S0958-9465(98)00025-0.

[22] J. White, R. Pleau, and F. Bouchard, "Innovative design with ultra-high performance concrete: A case study," in 2004 fib Symposium on Concrete Structures: The Challenge of Creativity, 2004: Association Francaise de Genie Civil, AFGC, pp. 234-235. [Online]. Available: https://www.scopus.com/inward/record.uri?eid=2-s2.0-850 07325090\&partnerID $=40 \& \mathrm{md} 5=\mathrm{b} 30661 \mathrm{a} 9153301299077$ b0flba7524f8. [Online]. Available: https://www.scopus.com/inward/record.uri?eid=2-s2.0-850 07325090\&partnerID=40\&md5=b30661a9153301299077 b0f1ba7524f8

[23] P. P. Li, M. J. C. Sluijsmans, H. J. H. Brouwers, and Q. L. $\mathrm{Yu}$, "Functionally graded ultra-high performance cementitious composite with enhanced impact properties," (in English), Compos Part B: Eng, Article vol. 183, 2020, Art no. 107680, doi: 10.1016/j.compositesb.2019.107680.

[24] E. Fehling, "Structures made of UHPC - Design and construction," (in German; English), Betonwerk Fertigteil Tech, Article vol. 70, no. 2, pp. 92-93, 2004.

[25] K. K. Sideris and A. E. Savva, "Durability of mixtures containing calcium nitrite based corrosion inhibitor," $\mathrm{Cem}$ Concr Compos, vol. 27, no. 2, pp. 277-287, 2005/02/01/ 2005, https://doi.org/10.1016/j.cemconcomp.2004.02.016.

[26] P. Chindaprasirt, C. Chotetanorm, and S. Rukzon, "Use of palm oil fuel ash to improve chloride and corrosion resistance of high-strength and high-workability concrete," (in English), J. Mater. Civ. Eng., Article vol. 23, no. 4, pp. 499-503, 2011, doi: 10.1061/(ASCE)MT.1943-5533.0000187.

[27] A. Çavdar and S. Yetgin, "Investigation of mechanical and mineralogical properties of mortars subjected to sulfate," (in English), Constr Build Mater, Article vol. 24, no. 11, pp. 2231-2242, 2010, doi: 10.1016/j.conbuildmat.2010.04.033.

[28] "Concrete and Durability of Concrete Structures," in 22nd International Materials Research Congress, IMRC 2013, Cancun, 2013, vol. 1612: Materials Research Society. [Online]. Available: http://www.scopus.com/inward/record.url?eid=2-s2.0-848 99516985\&partnerID $=40 \& \mathrm{md} 5=4 \mathrm{aa} 7 \mathrm{c} 62532 \mathrm{bbbadafd} 001$ be0732b5822. [Online]. Available: http://www.scopus.com/inward/record.url?eid=2-s2.0-848 99516985 \&partnerID $=40 \& \mathrm{md} 5=4 \mathrm{aa} 7 \mathrm{c} 62532 \mathrm{bbbadafd} 001$ be 0732 b5 522

[29] B. A. Salami, M. A. M. Johari, Z. A. Ahmad, and M. Maslehuddin, "POFA-engineered alkali-activated cementitious composite performance in acid environment," (in English), J. Adv. Concr. Technol., Article vol. 15, no. 11, pp. 684-699, 2017, doi: 10.3151/jact.15.684. 